\section{Global Proceedings Repository \\ American Research Foundation}

ISSN 2476-017X

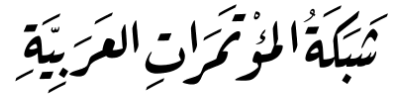

http://arab.kmshare.net/

Available online at http://proceedings.sriweb.org/akn/

AASRC-ARF JOINT INTERNATIONAL ACADEMIC CONGRESS ON

POLITICS, ENGINEERING, SOCIOLOGY, INFORMATION, HEALTH \& MEDICAL, EDUCATION AND COMMUNICATION 25-26 October, 2017

Istanbul Aydın University, Istanbul

$$
\begin{gathered}
\text { المؤتم الكاديمي الدولي الثامن عشر - في رحاب جامعة اسطنبول ايدن | 25- } 26 \text { اكتوبر } 2017 \text { اسطنبول - تككيا }
\end{gathered}
$$

\title{
İşgücü Piyasası İçin Bir Sosyal Sermaye Puanı Hesaplama Önerisi
}

\author{
İnci Parlaktuna, ${ }^{a}$ Tuğba Saraç ${ }^{b}$, Oytun Meçik ${ }^{c}$, Eren Can Aybek \\ ${ }^{a}$ Eskişehir Osmangazi Üniversitesi, İ̈BF, İktisat Bölümü, Eskişehir, TR \\ incip@ogu.edu.tr \\ ${ }^{\mathrm{b}}$ Eskişehir Osmangazi Üniversitesi, MMF, Endüstri Mühendisliği Bölümü, Eskişehir, TR \\ tsarac@ogu.edu.tr \\ ${ }^{c}$ Eskişehir Osmangazi Üniversitesi, İ̈BF, İktisat Bölümü, Eskişehir, TR \\ oytunm@ogu.edu.tr \\ ${ }^{d}$ Pamukkale Üniversitesi, Eğitim Fakültesi, Eğitim Bilimleri Bölümü, Denizli, TR \\ erencan@aybek.net
}

Öz. İşü̈cü piyasası açısından sosyal sermaye, işgücü ile işveren arasındaki güvene dayalı ilişkilerden doğan bir değerdir. Sosyal sermaye birikimine sahip olan üniversite mezunlarının, iş arama sürelerinin kısalması ve niteliklerine uygun işlerle eşleşmesi ve daha görünür hale gelmesi beklenmektedir. Bu bağlamda, mezunların sosyal sermaye birikimini öğrencilikleri süresince edinmeleri gerekliliği ön plana çıkmakta ve böylece üniversitelere, bu birikimi kazandıracak kanalların oluşturulması sorumluluğu yüklenmektedir. İşgücü piyasasının talep tarafında, işverenler istihdam kararı alırken; adayın akademik ortalamasından öte, bireyin sosyal sermaye birikimi ve bu yolla alanda edindiği deneyim ve tecrübeleri ve hatta sosyal yaşamındaki sosyal sermaye ve etkinlikleri fazlasıyla önemsemektedir. Ancak adayın alana 


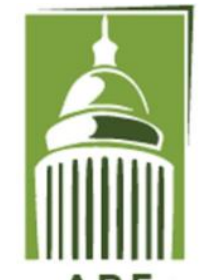

ARF

\section{Global Proceedings Repository \\ American Research Foundation}

ISSN 2476-017X

Available online at http://proceedings.sriweb.org/akn/

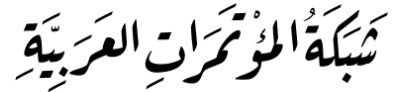

http://arab.kmshare.net/

özgü sosyal sermayesini gösteren somut bir göstergenin olmaması, işverenin seçim yapmasını güçleştirmekte, çoğu zaman akraba, yakın çevre gibi sınırlayıcı nitelikte sosyal sermaye kanallarını işletmesine ve böylece işgücü piyasasının etkinliğinin bozulmasına neden olmaktadır. Böyle bir göstergenin elde edilmesi işverenin daha etkin karar verebilmesini sağlayacaktır. Çalışmada mezunların alanlarına dair sosyal sermaye birikimini belirlemeye yönelik bir puanın hesaplanması hedeflenmektedir. Bunun için Analitik Hiyerarşi Prosesi (AHP) yöntemi kullanılmıştır. AHP, farklı önceliklere sahip birden fazla kriterin sistematik olarak karşılaştırılıp değerlendirilmesini sağlamaktadır. Genellikle AHP seçenekler içinden en iyisinin belirlenmesinde kullanılan bir teknik olmasına rağmen bu çalışmada yaygın kullanımından farklı olarak mezunların sosyal sermaye birikimlerini değerlendirmekte kullanılabilecek birden çok kriterin önem derecelerini göz önünde bulundurarak birleştirilmesi ve tek bir puana dönüştürülmesinde kullanılmıştır.

Keywords: Sosyal sermaye, işgücü piyasası, istihdam, analitik hiyerarşi prosesi, AHP, sosyal sermaye puanı, eğitim-iş uyumu.

\section{GíRiș}

Sanayi devrimi döneminde fiziki sermaye ve işgücü, temel üretim faktörleri olarak tanımlanırken, beşeri sermaye ve sosyal sermaye bilgi toplumu döneminde ön plan çıkmış ve yeni üretim faktörleri olarak ekonomi teorisine katılmıştır (Collois vd., 2005: 3-4). Genel kabul gören OECD (2001)'deki tanıma göre sosyal sermaye, ortak değerlerin paylaşımını sağlayan ve bu yolla bireylerin iletişimini kuvvetlendirerek toplumsal faaliyetleri kolaylaştıran ağlardır (Cote ve Healy, 2001: 12). Putnam'a (1995) göre sosyal sermaye iletişim ağları, güven ve normlar çerçevesinde en az iki kişinin arasında oluşan güvenin temel oluşturduğu yapılar olarak ifade edilmektedir. Bu bağlamda kişi ve kurumlar arasındaki güvene dayalı ilişkilerin niteliği ve niceliğindeki seviyeyi gösteren sosyal sermaye, ilgili alanın etkinliği ile doğrudan ilişkilidir. Sosyal sermaye ile ekonomik büyüme arasında güçlü bir ilişki vardır ve bu ilişki düzeyini gösteren çok sayıda ampirik çalışma bulunmaktadır (Bjornskov, 2005: 2-3; Bassani vd., 2001: 24).

Literatürde sosyal sermaye üç farklı tür olarak ele alınmaktadır. Bunlardan birincisi; bağlayıcı sosyal sermaye; eşit bireyler (aile bireyleri ve yakın arkadaşlar) arasında kurulan yatay ilişkilerden oluşur. Bu tür sosyal sermaye homojen ve aynı değer yargılarını paylaşan gruplardan oluşur ve en yüksek güven düzeyine sahiptir. İkincisi köprï kurucu sosyal sermaye; bir amaç için kurulmuş olan ve yatay ilişkiler sonucu ortaya çıkmıştır (Woolcock, 2001: 10-11). Üçüncü tür olan birleştirici sosyal sermaye; yatay dikey olabilen heterojen gruplar arasında oluşur (Lin, 1999: 38). Ekonomik etkinliği en yüksek olan sosyal sermaye türüdür.

Sosyal sermayeyi her boyutta ele almak imkân dâhilinde olduğu halde bu çalışmada, işgücü piyasasındaki sosyal sermayeye odaklanılmaktadır. Grannovetter (1995) göre, iş arayanların büyük bir oranı sosyal sermaye ile kurulan ağlar ile istihdam edilmektedirler. Sosyal sermaye 


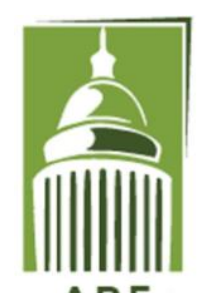

ARF

\section{Global Proceedings Repository \\ American Research Foundation}

ISSN 2476-017X

Available online at http://proceedings.sriweb.org/akn/

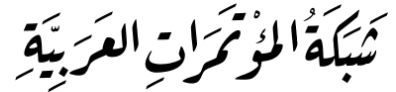

http://arab.kmshare.net/

ile işsizlik arasındaki temel ilişki, işgücü arzı ile işgücü talebinin ortak bir alanda buluştuğunu ve bilginin hızlı bir şekilde aktığını göstermektedir. Asimetrik bilginin ortadan kalktığı bu durum hem iş arama süresinin kısalmasına hem de işgücü piyasasının etkinliğinin arttırmasına neden olmaktadır. Sosyal sermayenin işgücü piyasası üzerindeki etkisi aşağıdaki gibi siralanabilir (Freitag ve Kirchne, 2011: 393):

- İş arama maliyetlerin düşürür.

- İşgücü piyasasında etkin eşleşmeyi sağlar.

- Kişiler işgücü piyasasındaki açık işlerden haberdar olur.

- İçerdekilerin dışardakilerine olan baskısı azalır (işverene yetişmiş işgücüne ulaşma imkânı sağlar).

- İşgücü piyasasında etkinliği arttırır ve ekonomik büyümeyi gerçekleştirir.

İşgücü piyasası sosyal sermaye türlerine göre yorumlandığında, bağlayıcı ve köprü kurucu sosyal sermaye türleri ile edinilen işlerde işin niteliği ile işgücünün niteliğinin doğru eşleşmediği, bu işlerin getirisinin düşük olduğu ve işi kaybetme riskinin daha yüksek olduğu, bu nedenlerle de işgücü piyasasının etkinliğinin bozulduğu ifade edilebilir (Bentolila vd., 2004). Bağlayıcı sosyal sermayenin işsizliği arttıııcı yönde etkisinin olduğunu (David, Janiak ve Wasmer, 2008), birleştirici sosyal sermayenin işsizliği düşürmede daha anlamlı olduğunu ve iş bulmayı pozitif yönde etkilediğini (Granovetter, 1995; Montgomery, 1991; Mouw, 2003) gösteren birçok çalışma mevcuttur. İşsizliğin azaltılmasında sadece ekonomik politikalar yeterli olmamaktadır. İşveren ile işgücü arasındaki koordinasyon bozuklukları, iş bulma sürecinin uzamasına neden olarak, işsizliğin artmasına veya işgücünün niteliklerinin altındaki konumlarda çalışmasına neden olarak işgücü piyasasının verimliliğini olumsuz etkilemektedir. İşveren ile işgücü arasından sosyal sermayenin güçlendirilmesi işgücü piyasasında doğru eşleşmeyi sağlayarak işgücü piyasasının ve ekonominin verimliliğini arttırmaktadır. Sosyal sermayenin geliştirilmesine yönelik politikalar işsizlik sorununun çözümü için güçlü bir politika önerisi olarak düşünülmektedir (Grannovetter, 1995: 51-52). Sosyal sermayenin işgücü piyasasındaki pozitif etkilerini sadece makro boyutta değil, mikro boyutta da görebilmek mümkündür. Sosyal sermayenin firmaların yönetim giderlerinin azalmasında, kredi faizlerinin düşmesinde ya da çalışanların verimliliğinin artmasında son derece önemli etkisinin olduğunun altı çizilmektedir (Torsvik, 2000).

Çalışmada üniversiteden mezun olan öğrencilerin eğitim-öğretim sürecinde bölümlerinin sağladıkları kanallarla edindikleri sosyal sermaye birikimini gösteren bir "sosyal sermaye puanı" belirlemeyi amaçlamaktadır. Mezunların eğitim aldıkları sürede alanları ile ilgili bilgi donanımının yanı sıra işveren ile bağlarını oluşturacak sosyal sermaye birikimi ve bu birikim aracılıyla alanlarında deneyim ve tecrübe edinilmeleri önemlidir. Bu tür donanıma sahip olmayan mezunların, iş arama süresinin uzaması veya işsiz kalması gibi sorunlarla karşı karşıya gelebilmesi, hatta ekonomik kaygılar nedeniyle nitelikleri altındaki konumlarda çalışmaları sıklıkla karşılaşılan sorunlardır. İşgücü piyasasında doğru eşleşmenin olmaması ve 


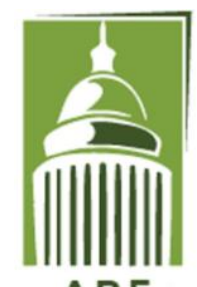

ARF

\section{Global Proceedings Repository \\ American Research Foundation}

ISSN 2476-017X

Available online at http://proceedings.sriweb.org/akn/

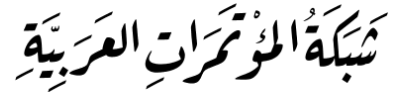

http://arab.kmshare.net/

işgücü piyasasının etkinliğinin bozulması, hem iktisadi birimler hem de genel ekonomik açıdan maliyet olarak değerlendirilmektedir. Bu tür maliyetlerin azaltılmasında üniversitelere önemli roller düşmektedir. Bu roller şu şekilde açıklanabilir; bölümler eğitim öğretim programını hazırlarken öğrencisine alan bilgisini kazandıran ders programının yanı sıra mezuniyet sonrasında kısa sürede ve doğru bir eşleşme ile işgücü piyasasına aktaracak olan sosyal sermaye birikimi kazandıracak kanallar açabilir. Bu doğrultuda, staj yaptırma, uygulamalı bitirme ödevi yaptırma, teknik gezi düzenleme, proje yaptırma, yarı zamanlı çalı̧̧ma imkânı sunma gibi faaliyetler ile ilgili sosyal sermaye birikimi edinilebilecek birçok kanal üretilebilecektir. Mezunlar, öğrencilikleri sırasında bu kanallar sayesinde sosyal sermaye birikimi edinebilirler, alanları ile ilgili deneyim ve tecrübede kazanabilir, iş yaşamına daha kolay ve doğru bir eşleşme ile geçebilirler.

Günümüzde işverenin istihdam kararı alırken adayın akademik ortalaması yanı sıra alanındaki sosyal sermaye birikimini ve bu yolla edindiği deneyim ve tecrübesini ve hatta sosyal yaşamındaki sosyal sermayesini ve etkinliklerini daha fazla önemsediği bilinmektedir. Çünkü firmalar istihdam ederken işi doğru bir şekilde yapacak ve bitirebilecek ve sürdürebilecek özelliklere sahip kişi/kişiler aramaktadırlar. Firmalar potansiyel elemanlarını; staj, bitirme ödevi gibi çalışmalar sırasında bu yönleri ile tanımakta ve aradıkları aday olup olmadığına bu süreçte karar vermekte, adaylar da bu tür bir iş yerinde çalışıp çalışmayacaklarının kararını deneyimleyerek vermektedirler.

Sosyal sermaye birikimini temsil eden bir sosyal sermaye puanı, işverenin istihdam kararını verirken doğru eşleşmeyi yapacak şekilde seçim yapma olasılığını artırabilir. Sosyal sermaye puanının olmaması işverenin seçim yapmasını zorlaştırmakta, çoğu zaman akraba, yakın çevre gibi sosyal sermaye kanallarına yönelmesine neden olmakta ve bu durumda da işgücü piyasasının etkinliği bozulabilmektedir. Eğer potansiyel mezunların sosyal sermaye birikimini temsilen bir puanı ortaya konabilirse, işveren işgücü piyasasını etkin olacağı şekilde adayları nispi olarak daha sağlıklı şekilde seçebilecektir.

Çalışmada bu doğrultuda, sosyal sermaye puanlarını belirlemede Analitik Hiyerarşi Prosesi (AHP) yöntemi kullanılmıştır. Sosyal sermaye puanı bu yöntemle birden fazla kriterin, önem dereceleri (firmaların ortaya koyduğu görüşler ve kriterler) dikkate alınarak birleştirilebilmesi ve tek bir değerlendirme değerine dönüştürülebilmesi için hesaplanmaktadır.

Çalışma dört bölümden oluşmaktadır. Giriş kısmında sosyal sermaye kavramı tanıtılmış ve işgücü piyasasındaki önemi ve sosyal sermaye puanı önerisine yönelik gereksinim ortaya konulmuştur. İkinci kısımda işgücü piyasasında sosyal sermayenin önemi ile ilgili literatür çalışmalarına yer verilmiştir. Üçüncü kısımda AHP yönteminin tanımı ve kullanıldığı yerlerden bahsedilmiş̧ir. Dördüncü kısımda ise sosyal sermaye puanını AHP yöntemi nasıl hesaplanacağı tasarlanmış ve bir uygulama önerisi açıklanmıştır. Son olarak beşinci bölümde sonuca yer verilmiştir. 


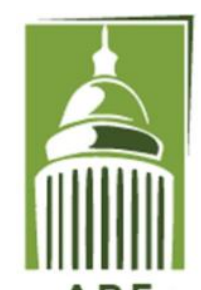

ARF

\section{Global Proceedings Repository \\ American Research Foundation}

ISSN 2476-017X

Available online at http://proceedings.sriweb.org/akn/

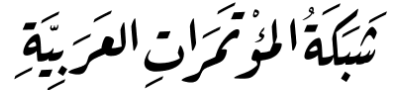

http://arab.kmshare.net/

\section{SOSYAL SERMAYENİN İŞGÜCÜ PIYASASINDAKİ FONKSIYYONLARI}

"Sosyal kurumun koordine edilmiş eylemleri kolaylaştırarak toplumun etkinliğini arttıran güven, normlar ve iletişim ağları gibi özellikleri” tanımı ile Putnam (1993: 169)'da çerçevesi çizilen sosyal sermaye, sosyal ağların, bir değere sahip olduğu düşüncesine dayanır (Putnam, 2000: 19). Böylelikle insan ve dolayısıyla toplum ilişkilerinde yer alan sosyal sermaye dinamiklerinin bu ilişkilerden doğan çıktılar üzerinde etkili olduğunu, verimliliği etkilediğini söylemek mümkündür. Zira yüksek sosyal sermaye birikimine sahip toplumların; daha güvenli, ahlaklı, zengin, kültürlü, iyi yönetilen ve dolayısıyla genel olarak daha mutlu toplumlar olduğuna dair tespitler söz konusudur. Çünkü bu toplumlarda iyi işler bulabilmek ve işlerin sürdürülmesi, hatta toplum yararına projeler üretilebilmesi, mevcut kaynakların daha etkin kullanılabilmesi, anlaşmazlıkların daha dostça çözülebilmesi imkân dâhilindedir (Woolcock, 1998: 155).

Sosyal sermaye, bir sermaye türü olarak, ekonomide önemli bir kaynaktır. Disiplinler arası ilgiye konu olması, yeterli ölçüde kavranabilmesinin önüne geçse de, sosyal sermaye, toplumsal yaşamın esasını oluşturan insanlar arası ilişkilerden kaynaklanması nedeniyle büyük bir öneme sahiptir (Onyx \& Bullen, 2000: 24; Lin, 2001: 4). Böylece ekonomi teorisi, sosyal ilişkileri bir çerçevenin içine oturtmakta ve diğer sermaye türlerini kurguladığ gibi sosyal sermayeyi de ekonomik büyüme dinamikleri arasına eklemektedir. Bu doğrultuda, bu dinamiğin pek çok farklı boyut ve kanaldan hareketle gerçekleşmesi söz konusudur. Bunu, sosyal sermayeyi; mikro, orta ve makro olmak üzere üç seviye ile ifade ederek açıklamak mümkündür. Bu tasnife göre, birey, aile ve arkadaşlar mikro seviyede yer almaktadır. $\mathrm{Bu}$ seviyede, bireylerin diğer bireylerle yaptıkları işler, grup üyelikleri, siyasal tercihleri, komşuluk ilişkileri, kişilere duydukları güven ve bireylere yardım etme duyarlılıkları gibi özellikler irdelenir (O’Brien, Burdsal \& Molgaard, 2004: 1207-1208). Bundan daha ötede konumlanan komşuluk, toplumsal kimlik ve yerel otoriteler orta seviye olarak tanımlanırken, bölgesel, ulusal ve uluslararası kavramlar makro seviye kapsamındadır (Altay, 2007: 344). Sosyal sermayeye ilişkin tanımlamalar; sosyal sermayenin grup üyeleri için pozitif dışsallık yarattı̆̆ $\breve{v}$ ge güven, normlar ve değerler gibi unsurların bireylerin beklentileri ve davranışları üzerindeki etkisinin, karşılıklılık esasına dayanarak gayri resmi sosyal ağlar ve birlikler aracılığıyla ortaya çıktığını göstermektedir (Durlauf \& Fafchamps, 2004: 5). Dolayısıyla sosyal sermayenin literatürde; güven, sosyal ağlar ve normlar gibi unsurlarla ele alındığı söylenebilir (Arrow, 1972, Sabatini, 2009; Fukuyama, 2001; Knack \& Keefer, 1997; Field, 2008, Çalışkan vd., 2014).

Sosyal sermayeyi temsil eden ya da bir dinamik haline getiren unsurlar ifade edildiği gibi bir miktar daha net durumda iken, sosyal sermayenin ölçülmesi ve özellikle ekonomik etkilerinin analiz edilebilmesi önemli bir karanlık noktayı oluşturmaktadır. Ancak sosyal sermayenin ölçülebilmesi halinde, elde edilmesini sağladığı getirilerin belirlenmesinin mümkün olacağı da aşikârdır. Bu yöndeki teşebbüsler bazı spesifik boyutlarda ortaya bazı tespitlerin konabilmesini sağlamıştır. Bunlara örnek olarak, eğitime katılımın yükselmesi ve okuldan terklerin önlenmesi (Halpern, 2005; Dinda, 2008; Knack \& Keefer, 1997), sosyal etkileşimin 


\section{Global Proceedings Repository \\ American Research Foundation}

ISSN 2476-017X

Available online at http://proceedings.sriweb.org/akn/

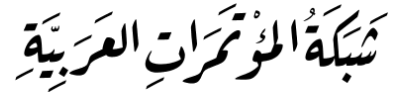

http://arab.kmshare.net/

ARF

dışsal yararları (Shideler \& Kraybill, 2009), radikal eğilimlerin önlenmesi (Çalışkan ve Meçik, 2010) ve özellikle meslek birlikleri açısından önemli olan ekonomik etkinliğin güçlenmesi olarak (Winch, 2000) gösterilebilir. Bu tespitlerin aynı zamanda, sosyal sermaye ve beşeri sermaye arasında da bir dirsek temasının söz konusu olduğunu da ortaya koyduğu göze çarpmaktadır (Çalışkan ve Meçik, 2011).

\section{YÖNTEM}

Analitik Hiyerarşi Prosesi (AHP), ilk olarak 1968 yılında Myers ve Alpert tarafindan ortaya atılmış ve 1977'de Profesör Thomas Lorie Saaty tarafından bir model olarak geliştirilerek karar verme problemlerinin çözümünde kullanılabilir hale getirilmiştir (Yaralığlu, 2001).

AHP, birden çok kriter içeren karmaşık problemlerin, hedefleri, kriterleri, alt kriterleri ve alternatifleri arasındaki ilişkileri gösteren hiyerarşik bir yapıda modellemelerine olanak verir. AHP'nin en önemli özelliği karar vericinin hem nicel hem de nitel kriterleri karar sürecine dâhil edebilmesidir. Bir başka deyişle AHP, bilginin, deneyimin, karar vericinin düşünce ve sezgilerinin mantıksal bir şekilde birleştirildiği bir yöntemdir. AHP, pazarlama, finans, eğitim, kamu politikaları, ekonomi, tıp, spor gibi pek çok uygulama alanına sahiptir ve birçok karar probleminin çözümünde etkin olarak kullanılmaktadır.

AHP yönteminin aşamaları aşağıdaki gibidir:

Adım 1. Karar Probleminin Tanımlanması ve Hiyerarşik Yapının Oluşturulması: Sürecin en önemli aşamasıdır. Çünkü karar probleminin ne olduğu, problemin hedefi, hangi kriterlere göre değerlendirme yapılacağı ve alternatifler bu aşamada belirlenir. Daha sonra hedef doğrultusunda bir karar hiyerarşisi oluşturulur. En üst seviyede hedef, orta seviyede kriterler ve en alt seviyede ise alternatifler yer alır (Saaty, 2008).

Adım 2. İkili Karşılaştırma Matrislerinin Oluşturulması: Hiyerarşik yapı oluşturulduktan sonra kriterlerin kendi aralarında karşılaştırılması ve her bir kriter bazında alternatiflerin karşılaştırılması için ikili karşılaştırma matrisleri oluşturulur (Saaty, 2008). Eğer alternatiflerin uzaklık, ağırlık gibi nicel özellikleri karşılaştırılıyorsa, ikili karşılaştırmalarda doğrudan ilgili sayısal değerler oranlanır. Eğer karşılaştırılan özellik nitel yapıda ise, ikili karşılaştırma matrisinin oluşturulmasında Tablo 1'de verilen AHP ikili karşılaştırmalar ölçeği kullanılmaktadır.

Tablo 1: AHP İkili karşılaştırmalar ölçeği

\begin{tabular}{cl}
\hline Önem derecesi & \multicolumn{1}{c}{ Tanım } \\
\hline 1 & Eşit önem \\
3 & Orta derecede önem \\
5 & Kuvvetli düzeyde önem \\
7 & Çok kuvvetli düzeyde önem \\
9 & Aşırı düzeyde önem
\end{tabular}




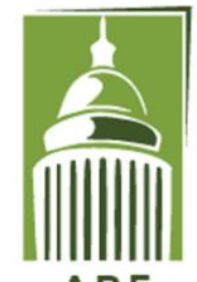

ARF

\section{Global Proceedings Repository \\ American Research Foundation}

ISSN 2476-017X

Available online at http://proceedings.sriweb.org/akn/

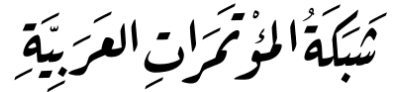

http://arab.kmshare.net/

\author{
$2,4,6,8 \quad$ Ara değerler
}

Adım 3. Göreli Önem Vektörlerinin (GÖV) Bulunması: Göreli önem vektörü, ikili karşılaştırma matrisinin her bir sütun değerinin ayrı ayrı ilgili sütun toplamına bölünmesi ve elde edilen matrisin her bir satırın aritmetik ortalamasının alınması ile bulunmaktadır (Saaty, 2008). Göreli önem vektörünün hesaplanmasında aritmetik ortalamanın yanı sıra, geometrik ortalama ya da ikili karşılaştırma matrisinin karesi de kullanılabilmektedir. Ancak matrisin boyutu büyüdükçe aritmetik ortalama, hesaplama kolaylığı nedeniyle daha çok tercih edilmektedir.

Adım 4. Tutarlılık Testi: Nicel özelliklerin karşılaştırıldığı ikili karşılaştırma matrislerinde karar vericiye ait bir yargı olmadığı için tutarlılık testi yapmaya gerek yoktur. Ancak nitel özelliklerin karşılaştırıldığı matrislerde değerlendirme hataları olabilir ve bu nedenle tutarlılık testinin mutlaka yapılması gerekmektedir. Tutarlılık testlerinin nasıl yapıldı̆̆ı ile ilgili ayrıntılı bilgiye Saaty (1980) başta olmak üzere pek çok kaynaktan erişilebilir.

Adım 5. Hiyerarşik Yapıya Ait Sonucun Elde Edilmesi: AHP'nin son adımı kriterlerin göreli önem vektörü ile alternatiflerin göreli önem vektörlerinin iç çarpımı ile her bir alternatife ait öncelik değerinin bulunmasıdır. Bu değerlerin toplamı 1'e eşittir. En yüksek değeri alan alternatif, karar problemi için en iyi alternatiftir (Saaty, 1980).

\title{
4 SOSYAL SERMAYE PUANININ HESAPLANMASI
}

Bu bölümde sosyal sermaye puanının AHP yöntemi ile nasıl hesaplanabileceği AHP adımları bazında açıklanmış ve ESOGÜ Mühendislik Mimarlık Fakültesi öğrencileri için örneklenmiştir.

Adım 1. Karar Probleminin Tanımlanması ve Hiyerarşik Yapının Oluşturulması:

Problemin hedefi, öğrencilere üniversiteleri tarafından kazandırılan sosyal sermayenin [0100] aralığında bir puan değeri ile ifade edilmesidir. Puan değerinin hesaplanmasında kullanılacak 13 kriter aşağıdaki gibi belirlenmiştir:

Kriter 1. Adayın yaptığı stajlar

Kriter 2. Adayın işverenin firmasında staj yapması

Kriter 3. Adayın bitirme ödevini sanayide uygulamalı olarak hazırlaması

Kriter 4. Adayın bitirme ödevini işverenin firmasında uygulamalı olarak hazırlaması

Kriter 5. Adayın araştırma projelerinde (BAP, TÜBİTAK vb.) yer alması

Kriter 6. Adayın mesleki kurum / kuruluş ve STK'lar ile ilişkileri

Kriter 7. Adayın yurtdışı öğrenci değişim programlarına (ERASMUS vb.) katılmış olması

Kriter 8. Adayın teknik gezi programlarına katılmış olması

Kriter 9. Adayın alanıyla ilgili kongre ve konferanslara katılmış olması

Kriter 10. Adayın öğrenciliği devam ederken mesleği ile ilgili yarı zamanlı çalışması

Kriter 11. Adayın ESOGÜ mezunu olması

Kriter 12. Adayı ESOGÜ'deki hocalarının yönlendirmesi 


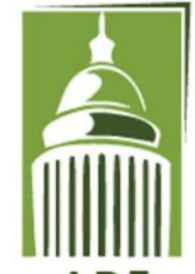

ARF

\section{Global Proceedings Repository \\ American Research Foundation}

ISSN 2476-017X

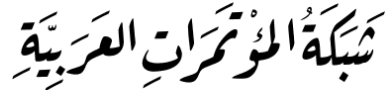

http://arab.kmshare.net/

Available online at http://proceedings.sriweb.org/akn/

Kriter 13. Adayın referans mektubu olmas1

Alternatifler ise sosyal sermaye puanları hesaplanacak öğrencilerdir. Eğer bir fakültenin ya da tüm üniversitenin öğrencileri için puan hesaplanacak ise alternatif sayısının oldukça fazla olabileceği açıktır.

Adım 2. İkili Karşılaş̧tırma Matrislerinin Oluşturulması:

Kriterler için ikili karşılaştırma matrisinin oluşturulabilmesi için ESOGÜ Bilimsel Araştırma Projeleri fonu tarafindan desteklenen ESOGÜ-MÜHSAN projesi kapsamında yapılan Firma Anketi ile elde edilen bilgiler kullanılmıştır. Söz konusu anketten alınan sorular ve her bir seçeneği tercih eden firma sayıları Tablo 2'de verilmiştir.

Tablo 2. Firma Anketi Soruları ve Her Bir Seçeneği Tercih Eden Firma Sayıları

\begin{tabular}{|c|c|c|c|}
\hline & $\begin{array}{l}\text { Katılmiyorum } \\
\text { diyen } \\
\text { Firma sayısı }\end{array}$ & $\begin{array}{c}\text { Kismen } \\
\text { kat1liyorum } \\
\text { diyen } \\
\text { Firma sayis1 } \\
\end{array}$ & $\begin{array}{l}\text { Katıliyorum } \\
\text { diyen } \\
\text { Firma sayısı }\end{array}$ \\
\hline 1.yaptığ1 stajlar işe almamı kolaylaştırır & 8 & 32 & 85 \\
\hline 2. firmamda staj yapması işe almamı kolaylaştırır. & 4 & 9 & 112 \\
\hline $\begin{array}{l}\text { 3. bitirme ödevini sanayide uygulamalı olarak hazırlaması işe } \\
\text { almamı kolaylaştırır. }\end{array}$ & 5 & 20 & 99 \\
\hline $\begin{array}{l}\text { 4. bitirme ödevini firmamda uygulamalı olarak hazırlaması işe } \\
\text { almamı kolaylaştırır. }\end{array}$ & 6 & 19 & 98 \\
\hline $\begin{array}{l}\text { 5. araştırma projelerinde (BAP, TÜBİTAK vb.) yer alması işe } \\
\text { almamı kolaylaştırır. }\end{array}$ & 7 & 35 & 81 \\
\hline $\begin{array}{l}\text { 6. mesleki kurum / kuruluş ve STK'lar ile ilişkileri işe almamı } \\
\text { kolaylaştırır. }\end{array}$ & 34 & 50 & 33 \\
\hline $\begin{array}{l}\text { 7. yurtdışı öğrenci değişim programlarına (ERASMUS vb.) } \\
\text { katılmış olması işe almamı kolaylaştıır. }\end{array}$ & 28 & 47 & 45 \\
\hline $\begin{array}{l}\text { 8. teknik gezi programlarına katılmış olması işe almamı } \\
\text { kolaylaştırır. }\end{array}$ & 47 & 46 & 28 \\
\hline $\begin{array}{l}\text { 9. alanıyla ilgili kongre ve konferanslara katılmış olması işe } \\
\text { almamı kolaylaştırır. }\end{array}$ & 24 & 57 & 40 \\
\hline $\begin{array}{l}\text { 10. öğrenciliği devam ederken mesleği ile ilgili yarı zamanlı } \\
\text { çalışması işe almamı kolaylaştırır. }\end{array}$ & 10 & 17 & 98 \\
\hline 11. ESOGÜ mezunu olması işe almamı kolaylaştırır. & 25 & 42 & 51 \\
\hline $\begin{array}{l}\text { 12. ESOGÜ'deki hocalarının yönlendirmesi işe almamı } \\
\text { kolaylaştırır. }\end{array}$ & 20 & 38 & 62 \\
\hline 13. referans mektubu olması işe almamı kolaylaştırır & 11 & 34 & 79 \\
\hline
\end{tabular}

Kritere ait ikili karşılaştırma matrisinin oluşturulabilmesi için karşılaştırmalarda kullanılmak üzere her bir kriter için bir ağılık değeri hesaplanacaktır. Bu amaçla Tablo 2'de yer alan 


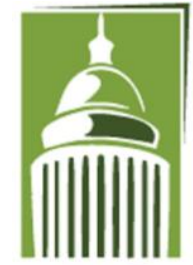

ARF
Global Proceedings Repository

American Research Foundation

ISSN 2476-017X

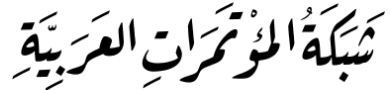

http://arab.kmshare.net/

Available online at http://proceedings.sriweb.org/akn/

'katılmıyorum' yanıt1 0 puan, 'kısmen katıliyorum' yanıtı 3 puan ve 'katılıyorum' yanit 5 puan kabul edilmiştir. Her kriter için yanıt puanları ile bu yanıtı seçen firma oranları çarpılarak toplanmış ve ilgili kriterin ağırlığı hesaplanmıştır. Hesaplanan kriter ağırlıkları Tablo 3'ün son sütununda verilmiştir.

Tablo 3. Kriter Ağırlıklarının Hesaplanması

\begin{tabular}{|c|c|c|c|c|c|c|c|c|}
\hline Puan & & 0 & & 3 & & 5 & & \\
\hline \multirow{2}{*}{ Yanit } & \multicolumn{2}{|c|}{ Katılmiyorum } & \multicolumn{2}{|c|}{ Kismen katıliyorum } & \multicolumn{2}{|c|}{ Katıliyorum } & \multirow[b]{2}{*}{$\begin{array}{r}\text { Toplam } \\
\text { firma } \\
\text { sayis } 1\end{array}$} & \multirow[b]{2}{*}{ Kriter Ağırlığg } \\
\hline & $\begin{array}{c}\text { Firma } \\
\text { sayıs1 }\end{array}$ & Firma oranı & $\begin{array}{c}\text { Firma } \\
\text { sayıs1 }\end{array}$ & Firma oranı & $\begin{array}{c}\text { Firma } \\
\text { sayısı }\end{array}$ & Firma oranı & & \\
\hline Kriter 1 & 8 & 0.064 & 32 & 0.256 & 85 & 0.68 & 125 & 5.528 \\
\hline Kriter 2 & 4 & 0.032 & 9 & 0.072 & 112 & 0.896 & 125 & 6.488 \\
\hline Kriter 3 & 5 & 0.04032258 & 20 & 0.16129032 & 99 & 0.7983871 & 124 & 6.072580645 \\
\hline Kriter 4 & 6 & 0.04878049 & 19 & 0.15447154 & 98 & 0.79674797 & 123 & 6.040650407 \\
\hline Kriter 5 & 7 & 0.05691057 & 35 & 0.28455285 & 81 & 0.65853659 & 123 & 5.463414634 \\
\hline Kriter 6 & 34 & 0.29059829 & 50 & 0.42735043 & 33 & 0.28205128 & 117 & 3.256410256 \\
\hline Kriter 7 & 28 & 0.23333333 & 47 & 0.39166667 & 45 & 0.375 & 120 & 3.8 \\
\hline Kriter 8 & 47 & 0.38842975 & 46 & 0.38016529 & 28 & 0.23140496 & 121 & 2.760330579 \\
\hline Kriter 9 & 24 & 0.19834711 & 57 & 0.47107438 & 40 & 0.33057851 & 121 & 3.727272727 \\
\hline Kriter 10 & 10 & 0.08 & 17 & 0.136 & 98 & 0.784 & 125 & 5.896 \\
\hline Kriter 11 & 25 & 0.21186441 & 42 & 0.3559322 & 51 & 0.43220339 & 118 & 4.093220339 \\
\hline Kriter 12 & 20 & 0.16666667 & 38 & 0.31666667 & 62 & 0.51666667 & 120 & 4.5666666667 \\
\hline Kriter 13 & 11 & 0.08870968 & 34 & 0.27419355 & 79 & 0.63709677 & 124 & 5.282258065 \\
\hline
\end{tabular}

Her bir kritere ait ağırlık değerleri birbiriyle oranlanarak kriterlere ait ikili karşılaştırma matrisi Tablo 4'te görülebileceği gibi elde edilmiştir.

Tablo 4. Kriterlere Ait İkili Karşılaştırma Matrisi

\begin{tabular}{|c|c|c|c|c|c|c|c|c|c|c|c|c|c|}
\hline & Kriter & Kriter & Kriter & Kriter & Kriter & Kriter & Kriter & Kriter & Kriter & Kriter & Kriter & Kriter \\
1 & 2 & 3 & 4 & 5 & 6 & 7 & 8 & 9 & 10 & 11 & Kriter \\
13
\end{tabular}




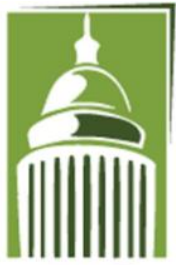

ARF
Global Proceedings Repository

American Research Foundation

ISSN 2476-017X

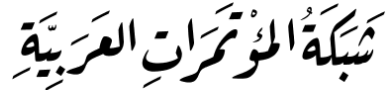

http://arab.kmshare.net/

Available online at http://proceedings.sriweb.org/akn/

\begin{tabular}{|l|l|l|l|l|l|l|l|l|l|l|l|l|l|}
\hline Kriter 1 & 1.00 & 1.17 & 1.10 & 1.09 & 0.99 & 0.59 & 0.69 & 0.50 & 0.67 & 1.07 & 0.74 & 0.83 & 0.96 \\
\hline Kriter 2 & 0.85 & 1.00 & 0.94 & 0.93 & 0.84 & 0.50 & 0.59 & 0.43 & 0.57 & 0.91 & 0.63 & 0.70 & 0.81 \\
\hline Kriter 3 & 0.91 & 1.07 & 1.00 & 0.99 & 0.90 & 0.54 & 0.63 & 0.45 & 0.61 & 0.97 & 0.67 & 0.75 & 0.87 \\
\hline Kriter 4 & 0.92 & 1.07 & 1.01 & 1.00 & 0.90 & 0.54 & 0.63 & 0.46 & 0.62 & 0.98 & 0.68 & 0.76 & 0.87 \\
\hline Kriter 5 & 1.01 & 1.19 & 1.11 & 1.11 & 1.00 & 0.60 & 0.70 & 0.51 & 0.68 & 1.08 & 0.75 & 0.84 & 0.97 \\
\hline Kriter 6 & 1.70 & 1.99 & 1.86 & 1.86 & 1.68 & 1.00 & 1.17 & 0.85 & 1.14 & 1.81 & 1.26 & 1.40 & 1.62 \\
\hline Kriter 7 & 1.45 & 1.71 & 1.60 & 1.59 & 1.44 & 0.86 & 1.00 & 0.73 & 0.98 & 1.55 & 1.08 & 1.20 & 1.39 \\
\hline Kriter 8 & 2.00 & 2.35 & 2.20 & 2.19 & 1.98 & 1.18 & 1.38 & 1.00 & 1.35 & 2.14 & 1.48 & 1.65 & 1.91 \\
\hline Kriter 9 & 1.48 & 1.74 & 1.63 & 1.62 & 1.47 & 0.87 & 1.02 & 0.74 & 1.00 & 1.58 & 1.10 & 1.23 & 1.42 \\
\hline Kriter 10 & 0.94 & 1.10 & 1.03 & 1.02 & 0.93 & 0.55 & 0.64 & 0.47 & 0.63 & 1.00 & 0.69 & 0.77 & 0.90 \\
\hline Kriter 11 & 1.35 & 1.59 & 1.48 & 1.48 & 1.33 & 0.80 & 0.93 & 0.67 & 0.91 & 1.44 & 1.00 & 1.12 & 1.29 \\
\hline Kriter 12 & 1.21 & 1.42 & 1.33 & 1.32 & 1.20 & 0.71 & 0.83 & 0.60 & 0.82 & 1.29 & 0.90 & 1.00 & 1.16 \\
\hline Kriter 13 & 1.05 & 1.23 & 1.15 & 1.14 & 1.03 & 0.62 & 0.72 & 0.52 & 0.71 & 1.12 & 0.77 & 0.86 & 1.00 \\
\hline
\end{tabular}

Çalışma kapsamında üniversite öğrencilerinin sosyal sermaye puanlarının hesaplanması amaçlandığından bu problemin alternatif sayısı puanı hesaplanacak ögrenci sayısına karşı gelmektedir. Değerlendirilecek alternatif sayısının çok fazla olması durumunda alternatiflere ait ikili karşılaştırma matrislerini oluşturmak oldukça zordur. Bu gibi durumlarda puanlama yöntemini kullanmak daha avantajlıdır. $\mathrm{Bu}$ yöntemde kriterler anlamlı şekilde bölümlendirilerek puan aralıkları belirlenmekte ve söz konusu puan aralıklarına göre her bir alternatife karşı gelen puanlar hesaplanabilmektedir. Örnek probleme ait kriterlerin bölümleri ve puanları Tablo 5'te verilmiştir.

Tablo 5. Kriterlerin Bölümlendirilmesi ve Puan Değerleri

\begin{tabular}{|c|c|c|c|c|c|c|}
\hline & Bölüm1 & Puan & Bölüm2 & Puan & Bölüm3 & Puan \\
\hline Kriter 1 & Gönüllü Staj Yok & 0 & En Az Bir Gönüllü Staj & 0.3 & Birden Fazla Gönüllü Staj & 0.7 \\
\hline Kriter 2 & Uygulamalı Değil & 0 & En Az Bir Uygulamalı Staj & 0.3 & Birden Fazla Uygulamalı Staj & 0.7 \\
\hline Kriter 3 & Teorik & 0 & Uygulamalı & 1 & & \\
\hline Kriter 4 & - & 0 & & & & \\
\hline Kriter 5 & Yok & 0 & En Az Bir & 0.3 & Birden Fazla & 0.7 \\
\hline Kriter 6 & Yok & 0 & En Az Bir & 0.3 & Birden Fazla & 0.7 \\
\hline Kriter 7 & Katılmadı & 0 & Katıldı & 1 & & \\
\hline Kriter 8 & Yok & 0 & En Az Bir & 0.3 & Birden Fazla & 0.7 \\
\hline Kriter 9 & Yok & 0 & En Az Bir & 0.3 & Birden Fazla & 0.7 \\
\hline Kriter 10 & Çalışmadı & 0 & Çalıştı & 1 & & \\
\hline
\end{tabular}




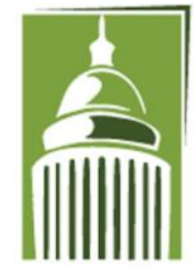

ARF
Global Proceedings Repository

American Research Foundation

ISSN 2476-017X

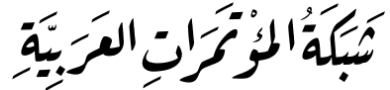

http://arab.kmshare.net/

Available online at http://proceedings.sriweb.org/akn/

\begin{tabular}{|l|c|l|c|l|l|l|}
\hline Kriter 11 & ESOGÜ'lü Değil & 0 & ESOGÜ'lü & 1 & & \\
\hline Kriter 12 & Yönlendirmedi & 0 & Yönlendirdi & 1 & & \\
\hline Kriter 13 & Yok & 0 & En Az Bir & 0.3 & Birden Fazla & 0.7 \\
\hline
\end{tabular}

Adım 3. Göreli Önem Vektörlerinin Bulunmasl:

Tablo 4'te yer alan ikili karşılaştırma matrisinin her bir sütunundaki elemanların ilgili sütun toplamına bölünmesi ile elde edilmiş normalleştirilirmiş matris Tablo 6'da ve bu matrisin satırlarında yer alan sayıların aritmetik ortalamaları ile elde edilen Kriterlere ait Göreli Önem Vektörü, Tablo 6'nın son sütununda verilmiştir.

Tablo 6. Normalleştirilmiş İkili Karşılaştırma Matrisi ve Göreli Önem Vektörü

\begin{tabular}{|c|c|c|c|c|c|c|c|c|c|c|c|c|c|c|}
\hline & $\begin{array}{c}\text { Kriter } \\
1\end{array}$ & $\begin{array}{c}\text { Kriter } \\
2\end{array}$ & $\begin{array}{c}\text { Kriter } \\
3\end{array}$ & $\begin{array}{c}\text { Kriter } \\
4\end{array}$ & $\begin{array}{c}\text { Kriter } \\
5\end{array}$ & $\begin{array}{c}\text { Kriter } \\
6\end{array}$ & $\begin{array}{c}\text { Kriter } \\
7\end{array}$ & $\begin{array}{c}\text { Kriter } \\
8\end{array}$ & $\begin{array}{c}\text { Kriter } \\
9\end{array}$ & $\begin{array}{c}\text { Kriter } \\
10\end{array}$ & $\begin{array}{c}\text { Kriter } \\
11\end{array}$ & $\begin{array}{c}\text { Kriter } \\
12\end{array}$ & $\begin{array}{c}\text { Kriter } \\
13\end{array}$ & G.Ö.V. \\
\hline $\begin{array}{c}\text { Kriter } \\
1 \\
\end{array}$ & 0.06 & 0.06 & 0.06 & 0.06 & 0.06 & 0.06 & 0.06 & 0.06 & 0.06 & 0.06 & 0.06 & 0.06 & 0.06 & \begin{tabular}{|c|}
0.063001 \\
862 \\
\end{tabular} \\
\hline $\begin{array}{c}\text { Kriter } \\
2 \\
\end{array}$ & 0.05 & 0.05 & 0.05 & 0.05 & 0.05 & 0.05 & 0.05 & 0.05 & 0.05 & 0.05 & 0.05 & 0.05 & 0.05 & $\begin{array}{c}0.053679 \\
762 \\
\end{array}$ \\
\hline $\begin{array}{c}\text { Kriter } \\
3\end{array}$ & 0.06 & 0.06 & 0.06 & 0.06 & 0.06 & 0.06 & 0.06 & 0.06 & 0.06 & 0.06 & 0.06 & 0.06 & 0.06 & $\begin{array}{c}0.057351 \\
942\end{array}$ \\
\hline $\begin{array}{c}\text { Kriter } \\
4 \\
\end{array}$ & 0.06 & 0.06 & 0.06 & 0.06 & 0.06 & 0.06 & 0.06 & 0.06 & 0.06 & 0.06 & 0.06 & 0.06 & 0.06 & $\begin{array}{c}0.057655 \\
099\end{array}$ \\
\hline $\begin{array}{c}\text { Kriter } \\
5 \\
\end{array}$ & 0.06 & 0.06 & 0.06 & 0.06 & 0.06 & 0.06 & 0.06 & 0.06 & 0.06 & 0.06 & 0.06 & 0.06 & 0.06 & $\begin{array}{c}0.063746 \\
635 \\
\end{array}$ \\
\hline $\begin{array}{c}\text { Kriter } \\
6\end{array}$ & 0.11 & 0.11 & 0.11 & 0.11 & 0.11 & 0.11 & 0.11 & 0.11 & 0.11 & 0.11 & 0.11 & 0.11 & 0.11 & $\begin{array}{c}0.106950 \\
374\end{array}$ \\
\hline $\begin{array}{c}\text { Kriter } \\
7 \\
\end{array}$ & 0.09 & 0.09 & 0.09 & 0.09 & 0.09 & 0.09 & 0.09 & 0.09 & 0.09 & 0.09 & 0.09 & 0.09 & 0.09 & \begin{tabular}{|l}
0.091651 \\
13
\end{tabular} \\
\hline $\begin{array}{c}\text { Kriter } \\
8 \\
\end{array}$ & 0.13 & 0.13 & 0.13 & 0.13 & 0.13 & 0.13 & 0.13 & 0.13 & 0.13 & 0.13 & 0.13 & 0.13 & 0.13 & \begin{tabular}{|c|}
0.126171 \\
227
\end{tabular} \\
\hline $\begin{array}{c}\text { Kriter } \\
9 \\
\end{array}$ & 0.09 & 0.09 & 0.09 & 0.09 & 0.09 & 0.09 & 0.09 & 0.09 & 0.09 & 0.09 & 0.09 & 0.09 & 0.09 & $\begin{array}{c}0.093439 \\
445\end{array}$ \\
\hline $\begin{array}{c}\text { Kriter } \\
10\end{array}$ & 0.06 & 0.06 & 0.06 & 0.06 & 0.06 & 0.06 & 0.06 & 0.06 & 0.06 & 0.06 & 0.06 & 0.06 & 0.06 & $\begin{array}{c}0.059069 \\
589\end{array}$ \\
\hline $\begin{array}{c}\text { Kriter } \\
11\end{array}$ & 0.09 & 0.09 & 0.09 & 0.09 & 0.09 & 0.09 & 0.09 & 0.09 & 0.09 & 0.09 & 0.09 & 0.09 & 0.09 & $\begin{array}{c}0.085085 \\
646\end{array}$ \\
\hline \begin{tabular}{|c|} 
Kriter \\
12 \\
\end{tabular} & 0.08 & 0.08 & 0.08 & 0.08 & 0.08 & 0.08 & 0.08 & 0.08 & 0.08 & 0.08 & 0.08 & 0.08 & 0.08 & $\begin{array}{c}0.076264 \\
444\end{array}$ \\
\hline $\begin{array}{c}\text { Kriter } \\
13\end{array}$ & 0.07 & 0.07 & 0.07 & 0.07 & 0.07 & 0.07 & 0.07 & 0.07 & 0.07 & 0.07 & 0.07 & 0.07 & 0.07 & $\begin{array}{l}0.065932 \\
844\end{array}$ \\
\hline
\end{tabular}

Adım 4. Tutarlılık Testi:

Tüm karşılaştırmalarda sayısal değerler kullanıldığından tutarlılık testi yapılmasına gerek yoktur.

Adım 5. Hiyerarşik Yapıya Ait Sonucun Elde Edilmesi:

Öğrencilerin Sosyal Sermaye Puanları (SSP)'nın nasıl hesaplandığını gösterebilmek için üç öğrenciye ait veriler rassal olarak türetilmiştir. Tablo 7'den de görülebileceği gibi, bir 


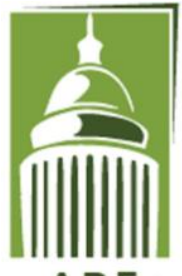

ARF
Global Proceedings Repository

American Research Foundation

ISSN 2476-017X

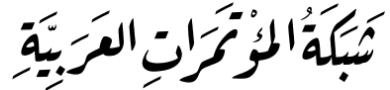

http://arab.kmshare.net/

Available online at http://proceedings.sriweb.org/akn/

öğrencinin kriterin hangi bölümüne ait puanı aldığı 1 ile işaretlenerek gösterilmiştir. Örneğin; Öğrenci-1 hiç gönüllü staj yapmamıştır. Bu nedenle, Kriter 1'e ait toplam puanı sıfırdır. Bir öğrencinin her bir kriterden aldığı puanları gösteren vektör ile GÖV'nün iç çarpımı ile öğrencinin ham puanı hesaplanır. Bu ham puanın [0-100] aralığında yer alacak şekilde düzeltilebilmesi için en yüksek puan değerinden yararlanılacaktır. Eğer bir öğrenci tüm kriterlere göre en yüksek puanları almış olsayd1, elde edebileceği en yüksek ham puan 0.770468 olacaktı. Bu değer, ham puanların SSP'ye dönüştürülmesinde $\mathrm{SSP}=100$ *(ham puan / 0.770468) formülünde kullanılmıştır. Ve öğrenci 1, 2 ve üçün sosyal sermaye puanları sırasıyla, 52, 86 ve 63 olarak hesaplanmıştır.

Tablo 7. Üç örnek öğrenci sosyal sermaye puanı hesabı

\begin{tabular}{|c|c|c|c|c|c|c|c|c|c|c|c|c|c|c|c|c|}
\hline & & $\begin{array}{l}0.06 \\
3001 \\
86 \\
\end{array}$ & $\begin{array}{l}0.05 \\
3679 \\
76 \\
\end{array}$ & $\begin{array}{l}0.05 \\
7351 \\
94 \\
\end{array}$ & $\begin{array}{l}0.05 \\
7655 \\
1 \\
\end{array}$ & $\begin{array}{l}0.06 \\
3746 \\
63 \\
\end{array}$ & $\begin{array}{l}0.10 \\
6950 \\
37 \\
\end{array}$ & $\begin{array}{l}0.09 \\
1651 \\
13 \\
\end{array}$ & $\begin{array}{l}0.12 \\
6171 \\
23 \\
\end{array}$ & $\begin{array}{l}0.09 \\
3439 \\
45 \\
\end{array}$ & $\begin{array}{l}0.05 \\
9069 \\
59 \\
\end{array}$ & $\begin{array}{l}0.08 \\
5085 \\
65 \\
\end{array}$ & $\begin{array}{l}0.07 \\
6264 \\
44 \\
\end{array}$ & $\begin{array}{l}0.06 \\
5932 \\
84 \\
\end{array}$ & & \\
\hline & & $\begin{array}{c}\text { Krite } \\
\text { r } 1\end{array}$ & $\begin{array}{c}\text { Krite } \\
\text { r } 2\end{array}$ & $\begin{array}{c}\text { Krite } \\
\text { r } 3\end{array}$ & $\begin{array}{c}\text { Krite } \\
\text { r } 4\end{array}$ & $\begin{array}{c}\text { Krite } \\
\text { r } 5\end{array}$ & $\begin{array}{c}\text { Krite } \\
\text { r } 6\end{array}$ & $\begin{array}{c}\text { Krite } \\
\text { r } 7\end{array}$ & $\begin{array}{c}\text { Krite } \\
\text { r } 8\end{array}$ & $\begin{array}{c}\text { Krite } \\
\text { r } 9\end{array}$ & $\begin{array}{c}\text { Krite } \\
\text { r } 10\end{array}$ & $\begin{array}{c}\text { Krite } \\
\text { r } 11\end{array}$ & $\begin{array}{c}\text { Krite } \\
\text { r } 12\end{array}$ & $\begin{array}{c}\text { Krite } \\
\text { r } 13\end{array}$ & $\begin{array}{l}\text { Ham } \\
\text { Puan }\end{array}$ & $\begin{array}{c}\text { SS } \\
\text { P }\end{array}$ \\
\hline \multirow{7}{*}{$\begin{array}{l}\ddot{O} \\
\stackrel{\mathrm{g}}{ } \\
\mathrm{r} \\
\mathrm{e} \\
\mathrm{n} \\
\mathrm{c} \\
\mathrm{i} \\
1\end{array}$} & $\begin{array}{c}\text { Bölüm } \\
1\end{array}$ & 1 & & & 1 & & & & & & 1 & 1 & & & & \\
\hline & Puan & 0 & 0 & 0 & 0 & 0 & 0 & 0 & 0 & 0 & 0 & 0 & 0 & 0 & & \\
\hline & $\begin{array}{c}\text { Bölüm } \\
2\end{array}$ & & 1 & 1 & & & 1 & 1 & 1 & 1 & & & 1 & 1 & & \\
\hline & Puan & 0.3 & 0.3 & 1 & & 0.3 & 0.3 & 1 & 0.3 & 0.3 & 1 & 1 & 1 & 0.3 & $\begin{array}{l}0.40 \\
3742 \\
\end{array}$ & 52 \\
\hline & $\begin{array}{c}\text { Bölüm } \\
3\end{array}$ & & & & & 1 & & & & & & & & & & \\
\hline & Puan & 0.7 & 0.7 & & & 0.7 & 0.7 & & 0.7 & 0.7 & & & & 0.7 & & \\
\hline & $\begin{array}{c}\text { Topla } \\
\text { m }\end{array}$ & 0 & 0.3 & 1 & 0 & 0.7 & 0.3 & 1 & 0.3 & 0.3 & 0 & 0 & 1 & 0.3 & & \\
\hline \multirow{7}{*}{$\begin{array}{l}\ddot{O} \\
\stackrel{\mathrm{g}}{ } \\
\mathrm{r} \\
\mathrm{e} \\
\mathrm{n} \\
\mathrm{c} \\
\mathrm{i} \\
2\end{array}$} & $\begin{array}{c}\text { Bölüm } \\
1 \\
\end{array}$ & & & & 1 & & & & & & 1 & & & & & \\
\hline & Puan & 0 & 0 & 0 & 0 & 0 & 0 & 0 & 0 & 0 & 0 & 0 & 0 & 0 & & \\
\hline & $\begin{array}{c}\text { Bölüm } \\
2\end{array}$ & 1 & & 1 & & 1 & & 1 & & & & 1 & 1 & & & \\
\hline & Puan & 0.3 & 0.3 & 1 & & 0.3 & 0.3 & 1 & 0.3 & 0.3 & 1 & 1 & 1 & 0.3 & $\begin{array}{l}0.66 \\
0699 \\
\end{array}$ & 86 \\
\hline & $\begin{array}{c}\text { Bölüm } \\
3\end{array}$ & & 1 & & & & 1 & & 1 & 1 & & & & 1 & & \\
\hline & Puan & 0.7 & 0.7 & & & 0.7 & 0.7 & & 0.7 & 0.7 & & & & 0.7 & & \\
\hline & $\begin{array}{c}\text { Topla } \\
\text { m }\end{array}$ & 0.3 & 0.7 & 1 & 0 & 0.3 & 0.7 & 1 & 0.7 & 0.7 & 0 & 1 & 1 & 0.7 & & \\
\hline $\begin{array}{l}\ddot{O} \\
\breve{g}\end{array}$ & $\begin{array}{c}\text { Bölüm } \\
1\end{array}$ & 1 & & & 1 & & & & & 1 & 1 & & & & & \\
\hline
\end{tabular}




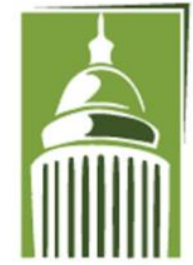

ARF
Global Proceedings Repository

American Research Foundation

ISSN 2476-017X

Available online at http://proceedings.sriweb.org/akn/

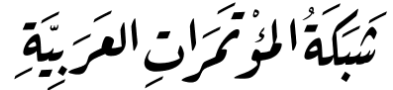

http://arab.kmshare.net/

\begin{tabular}{|c|c|c|c|c|c|c|c|c|c|c|c|c|c|c|c|c|}
\hline $\begin{array}{l}\mathrm{r} \\
\mathrm{e}\end{array}$ & Puan & 0 & 0 & 0 & 0 & 0 & 0 & 0 & 0 & 0 & 0 & 0 & 0 & 0 & & \\
\hline $\begin{array}{l}\mathrm{n} \\
\mathrm{c}\end{array}$ & $\begin{array}{l}\text { Bölüm } \\
2\end{array}$ & & 1 & 1 & & 1 & 1 & 1 & & & & 1 & 1 & 1 & & \\
\hline $\begin{array}{l}1 \\
3\end{array}$ & Puan & 0.3 & 0.3 & 1 & & 0.3 & 0.3 & 1 & 0.3 & 0.3 & 1 & 1 & 1 & 0.3 & $\begin{array}{l}0.48 \\
5766 \\
\end{array}$ & 63 \\
\hline & $\begin{array}{c}\text { Bölüm } \\
3\end{array}$ & & & & & & & & 1 & & & & & & & \\
\hline & Puan & 0.7 & 0.7 & & & 0.7 & 0.7 & & 0.7 & 0.7 & & & & 0.7 & & \\
\hline & $\begin{array}{c}\text { Topla } \\
\text { m }\end{array}$ & 0 & 0.3 & 1 & 0 & 0.3 & 0.3 & 1 & 0.7 & 0 & 0 & 1 & 1 & 0.3 & & \\
\hline
\end{tabular}

\section{SONUÇ}

Çalışmada hesaplanan sosyal sermaye puanı, işverenin istihdam kararını verirken doğru eşleşmeyi yapacak şekilde seçim yapma olasılığını artırması beklentisi ile üretilmiştir. Zira araştırmalar böyle bir somut göstergenin bulunmamasının işverenin seçim yapmasıını güçleştirdiğini ve belki de işin esaslarından ayrı kriterlerle karar verme durumunda bıraktığını ve böylece işgücü piyasasının etkinsiz hale geldiğini göstermektedir. Eğer potansiyel mezunların sosyal sermaye birikimini temsilen bir puanı ortaya konabilirse, işveren işgücü piyasasını etkin olacağı şekilde adayları nispi olarak daha sağlıklı ya da rasyonel şekilde seçebilecektir.

Sonuç olarak, bu çalışmada üniversite öğrencilerinin öğrencilikleri boyunca üniversitelerinin kanallarını kullanarak elde ettikleri sosyal sermaye puanlarının hesaplanabilmesine yönelik bir yöntem önerilmiştir. Önerilen yöntemle üç örnek öğrenci için sosyal sermaye puanları hesaplanmıştır. Böylece araştırma kapsamında elde edilen birincil veriler 1şı̆̆ında, işgücü piyasasının gereksinimleri dikkate alınarak, potansiyel mezunların eğitim süreçlerindeki edinimleri ile istihdam alanındaki gereksinimlerini uyumunu güçlendirecek bir öneri sunulmuştur.

\section{Bilgilendirme}

$\mathrm{Bu}$ çalışma, Eskişehir Osmangazi Üniversitesi Bilimsel Araştırma Projeleri Komisyonu tarafindan desteklenen 2016-852'nolu proje kapsamında türetilmiştir.

\section{Kaynaklar}

Altay, A. (2007). Bir kamu malı olarak sosyal sermaye ve yoksulluk ilişkisi. Ege Akademik Bakış, 7, 337-362.

Arrow, K. J. (1972). Gifts and exchanges. Philosophy and Public Affairs, 1 (4), 343-362.

Bentolila, S., Michelacci, C. \& Suarez, J. (2004). Social contacts and ocuupational choice. Economica, 77 (305), 20-45. 


\section{Global Proceedings Repository \\ American Research Foundation}

ISSN 2476-017X

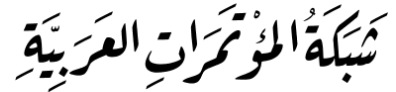

http://arab.kmshare.net/

Available online at http://proceedings.sriweb.org/akn/

Bjornskov, C. (2005). The muple facets of social capital. Eurepoean Journal of Economy, 22 (1), 22-40.

Callois, J. \& Aubert, F. (2005). Tords indicators of social capital for regional development issue. Fransa çevre ve sürdürülebilir kalkınma bakanlığı tarafından desteklenen bir proje.

Cote S. \& Healy T. (2001). The well being of nations, the role of human and social capital. Organization for Economic Cooperation and Development, Paris.

Çalışkan, Ş. \& Meçik, O. (2010). Sosyal sermayenin oluşumunda ve radikalleşmenin önlenmesinde eğitimin rolü. M. Sever, H. Cinoğlu ve O. Başıüyü̈k (Ed.), Terörün Sosyal Psikolojisi içinde (pp. 41-63), Ankara: Polis Akademisi Yayınları.

Çalışkan, Ş. \& Meçik, O. (2011). Sosyal ve beşeri sermayenin bireysel ekonomik getirisi üzerine uygulamalı bir analiz: "Eskişehir ili örneği". Paradoks Ekonomi, Sosyoloji ve Politika Dergisi, 7 (2), 7-26.

Çalışkan, Ş., Pehlivanoğlu, F. \& Meçik, O. (2014). Bireysel kazançların belirlenmesinde sosyal sermayenin rolü (Yalova örneği). Cumhuriyet Üniversitesi İktisadi ve İdari Bilimler Dergisi, 15 (1), 313-323.

David, Q., Janiak, A. \& Wasmer, E. (2008). Social capital, mobility and unemployment in Europe. Journal of Urban Economics, 68 (2), 191-201.

Dinda, S. (2008). Social capital in the creation of human capital and economic growth: a productive consumption approach. The Journal of Socio-Economics, 37, 2020-2033.

Durlauf, S. N. \& Fafchamps, M. (2004). Social capital. (Working Paper 10485), Cambridge: The National Bureau of Economic Research.

Field, J. (2008). Sosyal sermaye, (Çev.) B. Bilgen \& B. Şen. İstanbul: İstanbul Bilgi Üniversitesi Yayınları.

Freitag, M. \& Kirchne, A. (2011). Social capital and unemployment: a macro-quantitative analysis of the European region. Political Studies, 59 (2), 389-410.

Fukuyama, F. (2001). Social capital, civil society and development. Third World Quarterly, 22, 7-20.

Grannovetter, M. (1995). Investigsting causal relations by econometric models and crossspectral methods. Econometrica, 37 (3), 424-438.

Halpern, D. (2005). Social capital. Cambridge: Polity Press.

Knack, S. \& Keefer, P. (1997). Does social capital have an economic payoff? a cross-country investigation. The Quarterly Journal of Economics, 112 (4), 1251-1288.

Lin, N. (1999). Building a network theory of social capital. Connections, 22 (1), 28-51.

Lin, N. (2001). Building a network theory of social capital. N. Lin, K. Cook \& R. S. Burt (Ed.), In Social Capital Theory and Research (pp. 3-30), New York: Aldine De Gruyter. 


\section{Global Proceedings Repository \\ American Research Foundation}

ISSN 2476-017X

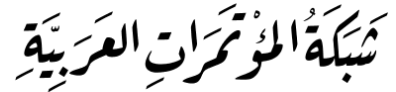

http://arab.kmshare.net/

Available online at http://proceedings.sriweb.org/akn/

Montgomery, J. D. (1991). Social networs and labor-market outcomes: toward an economic analysis. The American Economic Review, 81 (5), 1408-1418.

Mouw, T. (2003). Social capital and findind a job: do contacts and earnings. Labour Economics, 1, 187-207.

O'Brien, M. S., Burdsal, C. A. \& Molgaard, C. A. (2004). Further development of an australian-based meausure of social capital in a US sample. Social Science \& Medicine, 59, 1207-1217.

OECD (2001). The well-being of nations. The role of human and social capital. Paris: OECD Publications.

Onyx, J. \& Bullen, P. (2000). Measuring social capital in five communities. The Journal of Applied Behavioral Science, 36, 23-42.

Putnam, R. D. (1993). Making democracy work: civic traditions in modern Italy, New Jersey: Princeton University Press.

Putnam, R. D. (2000). Bowling alone: the collapse and revival of American community. New York: Simon \& Schuster Inc.

Putnam, R. D. (1995). Bowling alone: America's declining social capital. Journal of Democracy, 6 (1), 64-78.

Saaty T. L. (1980). The analytic hierarchy process. New York: McGraw-Hill.

Saaty, T. L. (2008). Decision making with the analytic hierarchy process. International Journal of Services Sciences, 1 (1), 83-94.

Sabatini, F. (2009). Social capital as social networks: a new framework for measurement and an empirical analysis of its determinants and consequences. The Journal of SocioEconomics, 38, 429-442.

Shideler, D. W. \& Kraybill, D. S. (2009). Social capital: an analysis of factors influencing investment. The Journal of Socio-Economics, 38, 443-455.

Torsvik, G. (2000). Social capital and economic development: a plea for the mechanizms. rationality and society. Rationality and Society, 12 (4), 451-476.

Winch, C. (2000). Education, work and social capital, London: Routledge.

Woolcock, M. (1998). Social capital and economic development: toward a theoretical synthesis and policy framework. Theory and Society, 27, 151-208.

Woolcock, M. (2001). The place of social capital in understanding social and economic outcomes. ISUNA, 11-17.

Yaralığlu, K. (2001). Performans değerlendirmede analitik hiyerarşi proses. Dokuz eylül üniversitesi iktisadi ve idari bilimler fakültesi dergisi, 16 (1), 129-142.

İnci Parlaktuna Eskişehir Osmangazi Üniversitesi İktisat bölümünde Doç.Dr. olarak görev 


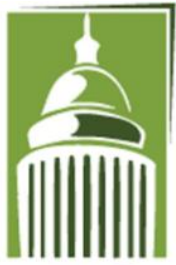

ARF

\section{Global Proceedings Repository \\ American Research Foundation}

ISSN 2476-017X

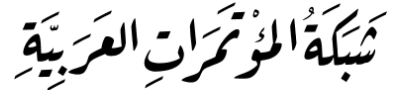

http://arab.kmshare.net/

Available online at http://proceedings.sriweb.org/akn/

yapmaktadır. Parlaktuna Yüksek Lisans eğitimini 1990 yılında Vanderbilt Üniversitesinde, Doktora eğitimini 1997 yılında Anadolu Üniversitesinde İktisat ABD tamamlamıştır. Para teorisi ve döviz kuru ve sosyal sermaye alanında çalışmaları bulunan Parlaktuna'nın kadın çalışmaları, kadının işgücü piyasasındaki konumu ve sorunları alanında da birçok çalışması bulunmaktadır. UNDP'nin ortak Sabancı Vakfinın hibe projesi “Toplumsal Cinsiyete Duyarlı Bütçeleme başlı̆̆ında iki adet projede danışmanlık yapmıştır. Parlaktuna Sağlıklı Kentler Birliği danışma kurulu üyesi, Eskişehir Tepebaşı Belediyesi Sağlıklı Kent Konseyi Yönetim Kurulu üyesidir.

Tuğba Saraç: Eskişehir Osmangazi Üniversitesi Endüstri Mühendisliği bölümünde öğretim üyesi olarak görev yapmaktadır. Lisans, yüksek lisans ve doktora eğitimini görev yapmakta olduğu bölümde yöneylem araştırması alanında tamamlamıştır. Araştırma alanları; matematiksel modelleme, modellerin kesin çözüm yaklaşımları ve yapay zeka teknikleri ile çözülmesidir.

Oytun Meçik: Eskişehir Osmangazi Üniversitesi İktisat Bölümünde Yardımcı Doçent Doktor olarak görev yapmaktadır. Meçik, Yüksek Lisans eğitimini 2010 yılında ve Doktora eğitimini de 2014 yılında İktisat alanında tamamlamıştır. İktisat alanında özellikle işgücü piyasası, sosyal ve ekonomik ağlar alanlarında çok sayıda çalışması bulunan Meçik, halen sosyal sermaye, işgücü piyasasında eğitim ve iş uyumsuzluğu hakkında çalışmalar yapmaktadır. Meçik, Türkiye Ekonomi Kurumu üyesidir.

Eren Can Aybek: Pamukkale Üniversitesi Eğitim Fakültesi'nde yardımcı doçent olarak görev yapmaktadır. Yüksek lisans ve doktora eğitimini ölçme ve değerlendirme alanında sırasıyla 2012 ve 2016 yıllarında tamamlamıştır. Ölçme aracı geliştirme, madde tepki kuramı ve bilgisayar ortamında bireye uyarlanmış testler konusunda çalışmalarını sürdürmektedir. 